\title{
The Research of the Different Properties and Production Parameters Having In- fluence on Deep-Drawing Sheets Made of AlMg3 Alloy
}

Štefan Michna, Iryna Hren, Jaromír Cais, Lenka Michnová

The University of J. E. Purkyně, Faculty of Mechanical Engineering, Ústí nad Labe, Pasteurova 3334/7, Czech Republic, E-mail: stefan.michna@ujep.cz, iryna.hren@ujep.cz, jaromir.cais@ujep.cz, lenka.michnova@ujep.cz

This work was focused on the research of the different variability production deep-drawing sheets made of AlMg3 alloy which could influence on their deep-drawing properties e.g. non alloying elements $\mathrm{Fe}$, $\mathrm{Mn}$, heat treatment parameters and structure with aim to judge ascertained and analyzed properties of the sheets. The mechanical properties, mainly the highest elongation, and the other parameters (grain size, metallurgical purity), were measured due to they had had the main influence on the deep-drawing properties of the sheets made of AlMg3 alloy. For this research work had been obtained 5 deep-drawing sheets made of AlMg3 alloy with different production than chemical composition and heat treatment with the aim to realized "complex analyze", and to find up the best variant for production technology with the high deep-drawing properties.

Keywords: AlMg3 alloy, mechanical properties, elongation of material, deep-drawing, chemical composition, aluminum sheets, metallurgical purity, EDS analyses, grain size

\section{Introduction}

The first test for evaluation the formability of sheet metal was proposed by Erichsen [1]. The test consists in stretching a sheet specimen by means of a hemispherical punch until the occurrence of fracture, see Fig. 1 [2]. The depth of the punch identification in the specimen expressed in millimeters is so-called Erichsen index. This is most commonly used parameter for expressing formability of sheet metals [3-9]. The index established using this method has a low accuracy due to the small size of the tools, the impossibility of a sound fixing of the specimen and poor lubrication. Erichsen test - it is technique which allow to obtain technological parameters of sheets according to ČSN EN ISO 20482, and their convenience for deep-drawing. It also allows to obtain information about adhesion and cohesion properties of coatings and layers.

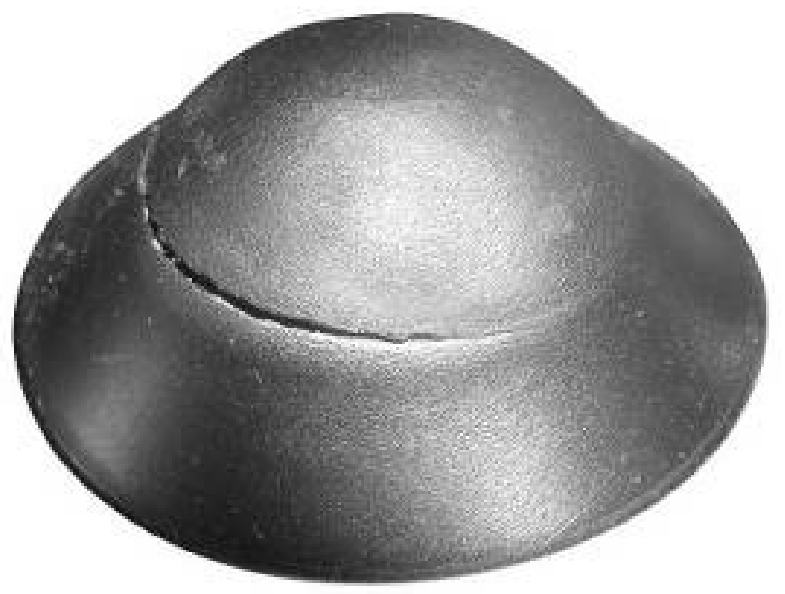

Fig. 1 Erichsen test with the fracture formation [2]
The fundamental way with direct coherence influenced on deep drawing is to obtain the highest plasticity(elongation) of material. Quantitative evaluations plasticity for given material is to obtain the most value of elongation for examined material, where is direct relation between elongation and deep-drawing where is validity that the highest value of elongation represents better deep-drawing of material. The main goal of this research work had been to obtain as high as is possible elongation for sheets made of AlMg3 alloy, and ascertained technological parameters production for this aim [10-14].

There are a lot of factors which influenced on elongation determined material, and we focused on, in this research work on several basic material properties at the sheets made of AlMg3 alloy which could be control with the aim to obtain the highest elongation. Within the various technological parameters obtained sheets made of $\mathrm{AlMg} 3$ alloy we had watched the following technological parameters on elongation and properties.

- Influence of chemical composition mainly influence of allowed admixture chemical elements within the standard.

- Influence of heat treatment within production of determined sheet (with/without between annealing, homogenization/without homogenization of basic material).

- Influence of metallurgical cleanest of finally produced sheet (evaluated on the fracture surface samples after static tensile test). 
- Influence of finally grain size (recommended grain size is $10-20 \mathrm{~nm}$ for obtaining the best elongation)

\section{Identification of analyzed samples}

The aim of this work had been research in the area with the different variants of production sheets made of AlMg3 alloy and had found up the best properties of sheets from the point of view the highest elongation (and also the best deep-drawing). For this research had been obtained 5 different variants of technologically product sheets made of AlMg3 alloy with the thickness $1,8 \mathrm{~mm}$ with the aim to realize "complex analyse" and found up optimal variant for technologically production of the sheets with the high elongation.

Designation of the sheet:

Sheet1 - without between annealing, and without homogenization with the highest content of $\mathrm{Mn}, \mathrm{Fe}$, and $\mathrm{Si}$

Sheet 2 - after homogenization with the very low content of $\mathrm{Mn}, \mathrm{Fe}$, and Si.

Sheet 3 - after homogenization and between annealing on the thickness $4 \mathrm{~mm}$ with the highest content of $\mathrm{Mn}$, and higher content of Fe.

Sheet 4 - without homogenization, between annealing on the thickness $4 \mathrm{~mm}$ with the higher content of Mn.

Sheet 5 - without homogenization, without between annealing on the thickness $4 \mathrm{~mm}$ with very low content of $\mathrm{Mn}, \mathrm{Fe}$, and $\mathrm{Si}$.

For these analyses we obtained 5 sheets made of AlMg3 alloy with the thickness $1,8 \mathrm{~mm}$ with the identification of forming direction. The Fig. 2 presented one of the obtained sheets (sheet designation as samples 1) with the identification took in places for static tensile test, microstructure analyses and spectral chemical analyses. Designation of analyses samples.

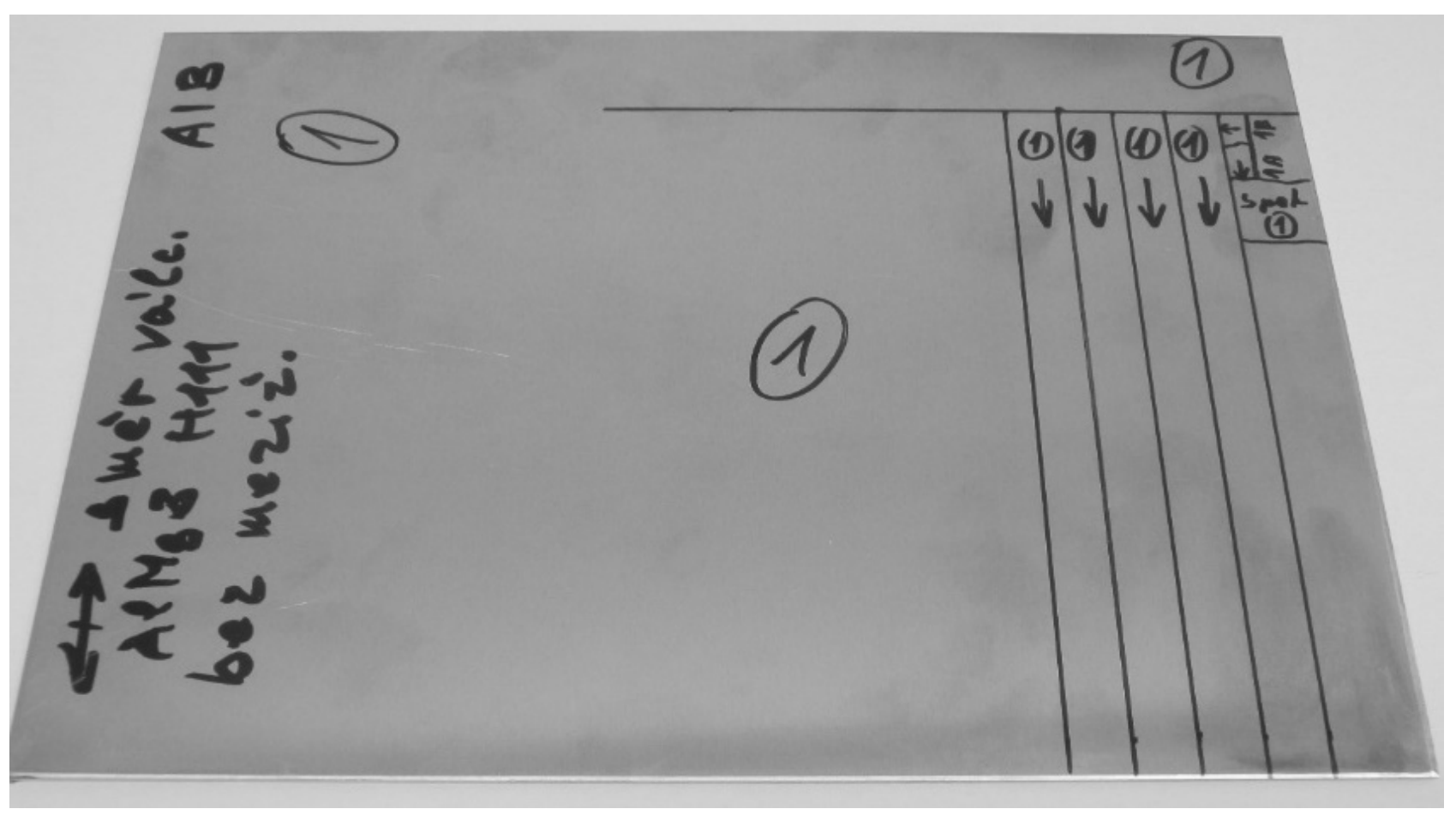

Fig. 2 Sheet 1- sheet made of AlMg3 alloy with identification take in places for static tensile test, and microstructure analyses and spectral chemical analyses

\section{Chemical analyses}

Chemical composition of individual sheet is given in the Table1. Total reports from spectral chemical analyses (realized by Q4 TASMAN) are given as appendix No. 3-7.

Tab. 1 Chemical composition of sheets 1-5 [wt.\%]

\begin{tabular}{|c|c|c|c|c|c|c|c|c|c|c|}
\hline Sheet & $\mathrm{Si}$ & $\mathrm{Fe}$ & $\mathrm{Cu}$ & $\mathrm{Mn}$ & $\mathrm{Mg}$ & $\mathrm{Cr}$ & $\mathrm{Ni}$ & $\mathrm{Zn}$ & $\mathrm{Ti}$ & $\mathrm{Al}$ \\
\hline 1 & 0.117 & 0.425 & 0.019 & 0.319 & 2.780 & 0.045 & 0.0058 & 0.027 & 0.032 & 96.14 \\
\hline 2 & 0.074 & 0.192 & $<0.001$ & 0.097 & 3.467 & $<0.002$ & 0.005 & 0.008 & 0.008 & 96.09 \\
\hline 3 & 0.118 & 0.716 & 0.018 & 0.214 & 3.109 & 0.155 & 0.051 & 0.027 & 0.019 & 95.51 \\
\hline 4 & 0.125 & 0.710 & 0.018 & 0.214 & 3.198 & 0.160 & 0.049 & 0.029 & 0.019 & 95.42 \\
\hline 5 & 0.069 & 0.231 & $<0.001$ & 0.068 & 2.656 & $<0.002$ & $<0.002$ & 0.014 & 0.009 & 96.87 \\
\hline
\end{tabular}


Comments: The sheet 2 has visible lower content of $\mathrm{Fe}$ and $\mathrm{Mn}$ against the sheets 1,3,4, summary 2-3 times lower. The sheet 3 and 4 have higher content of $\mathrm{Ct}$ if we compare them with the rest sheets. The sheet 5 has the nearest chemical composition to sample 2 mainly in the content of admixture chemical elements as $\mathrm{Fe}, \mathrm{Mn}, \mathrm{Cr}$, and $\mathrm{Si}$.

\section{Static tensile test}

Static tensile test had been realized by Inspect 100 equipment from Hegewald \& Pesche firm at the parameters according to ČSN EN 10002-1 (42 0310). Static tensile test for the samples had been realized at room temperature $20 \pm 2{ }^{\circ} \mathrm{C}$. Sped of loading for all samples had been $4 \mathrm{~mm} / \mathrm{min}$. Samples for static tensile test had been took in from the sheets in two different rolling directions (in the rolling direction and in the perpendicular to rolling direction). In the Figure 3 are shown samples distribution for static ensile test for obtained sheet.

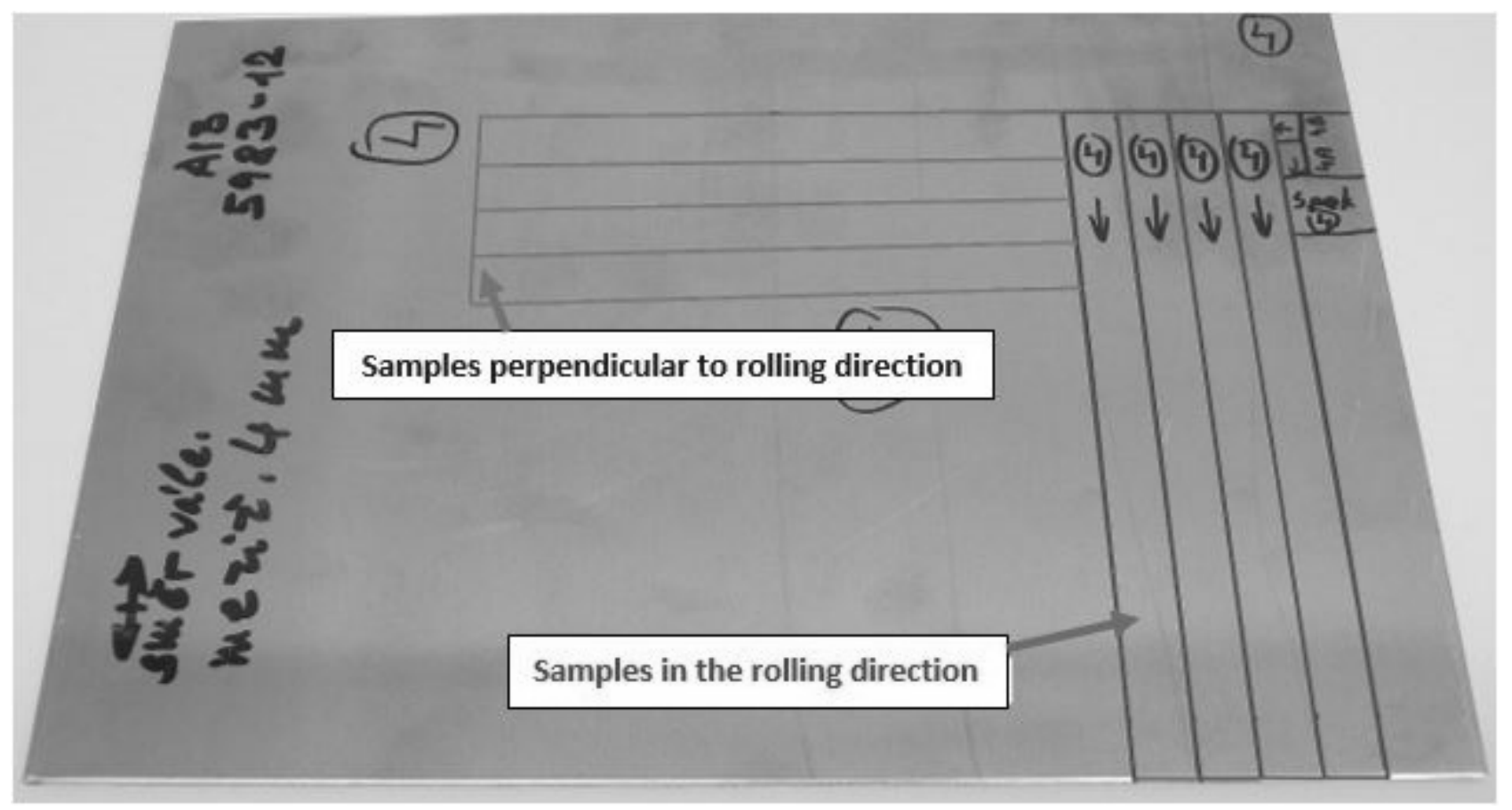

Fig. 3 Distribution of the samples for static tensile test

Results from the static tensile test are given in the Table 2. Samples made from perpendicular to rolling direction had been took in after samples in the rolling direction, and due to it had been impossible to produce more samples. As it is given in the Table 2 the highest values of tensile strength had been obtained in both directions in the sheet 3 and 4 . On the contrary these sheets had the lowest values of elongation. The highest values of elongation in the both directions had been ascertained in the samples made of sheet 5 , but these samples showed the lower values of tensile strength.

Tab. 2 Results from static tensile test.

\begin{tabular}{|c|c|c|c|c|c|c|}
\hline Sheet & Direction & Sample & $\mathrm{Rm}[\mathrm{MPa}]$ & $\varnothing \mathrm{Rm}[\mathrm{MPa}]$ & A [\%] & $\overline{\varnothing ~ A ~[\%] ~}$ \\
\hline \multirow{5}{*}{1} & \multirow{4}{*}{ Rolling direction } & $1-1$ & 234 & \multirow{4}{*}{236} & 21.1 & \multirow{4}{*}{21.1} \\
\hline & & $1-2$ & 246 & & 22.5 & \\
\hline & & $1-3$ & 236 & & 20.4 & \\
\hline & & $1-4$ & 227 & & 20.3 & \\
\hline & $\begin{array}{l}\text { Perpendicular to rolling } \\
\text { direction }\end{array}$ & $1-1 \mathrm{~K}$ & 226 & 226 & 20.7 & 20.7 \\
\hline
\end{tabular}

\begin{tabular}{|c|c|c|c|c|c|c|}
\hline \multirow{5}{*}{2} & \multirow{4}{*}{ Rolling direction } & $2-1$ & 236 & \multirow{4}{*}{237} & 26.3 & \multirow{4}{*}{24.7} \\
\hline & & $2-2$ & 237 & & 23.4 & \\
\hline & & $2-3$ & 237 & & 25.1 & \\
\hline & & $2-4$ & 237 & & 23.8 & \\
\hline & $\begin{array}{l}\text { Perpendicular to rolling } \\
\text { direction }\end{array}$ & $2-1 K$ & 223 & 223 & 23.9 & 24.1 \\
\hline
\end{tabular}




\begin{tabular}{|c|c|c|c|c|c|c|}
\hline \multirow{5}{*}{3} & \multirow{4}{*}{ Rolling direction } & $3-1$ & 259 & \multirow{4}{*}{259} & 24.3 & \multirow{4}{*}{20.7} \\
\hline & & $3-2$ & 259 & & 20.5 & \\
\hline & & $3-3$ & 257 & & 20.0 & \\
\hline & & $3-4$ & 259 & & 17.9 & \\
\hline & $\begin{array}{c}\text { Perpendicular to rolling } \\
\text { direction }\end{array}$ & $3-1 \mathrm{~K}$ & 243 & 242 & 19.1 & 20.4 \\
\hline
\end{tabular}

\begin{tabular}{|c|c|c|c|c|c|c|}
\hline \multirow{5}{*}{4} & \multirow{4}{*}{ Rolling direction } & $4-1$ & 260 & \multirow{4}{*}{260} & 20.3 & \multirow{4}{*}{20.9} \\
\hline & & $4-2$ & 260 & & 20.8 & \\
\hline & & $4-3$ & 260 & & 22.3 & \\
\hline & & $4-4$ & 260 & & 20.3 & \\
\hline & $\begin{array}{l}\text { Perpendicular to rolling } \\
\text { direction }\end{array}$ & $4-1 K$ & 242 & 244 & 20.8 & 20.5 \\
\hline
\end{tabular}

\begin{tabular}{|c|c|c|c|c|c|c|}
\hline \multirow{5}{*}{5} & \multirow{4}{*}{ Rolling direction } & $5-1$ & 219 & \multirow{4}{*}{218} & 33.8 & \multirow{4}{*}{35.1} \\
\hline & & $5-2$ & 217 & & 34.2 & \\
\hline & & $5-3$ & 218 & & 38.3 & \\
\hline & & $5-4$ & 216 & & 34.0 & \\
\hline & $\begin{array}{c}\text { Perpendicular to rolling } \\
\text { direction }\end{array}$ & $5-1 \mathrm{~K}$ & 208 & 209 & 33.0 & 34.8 \\
\hline
\end{tabular}

\section{Fracture surfaces EDS analyses.}

Scanning electron microscope (SEM) Tescan VEGA 3 with EDS analyzer Bruker was used for fracture surface analyses. Fracture surface analyses had been realized after static tensile test at chosen samples (sample 1-4). Fractography analyses were focused on presence brittle intermetallic particles on fracture surfaces, and on presence foreign particles which could been the reason of fracture.

\section{Sample 1-4}

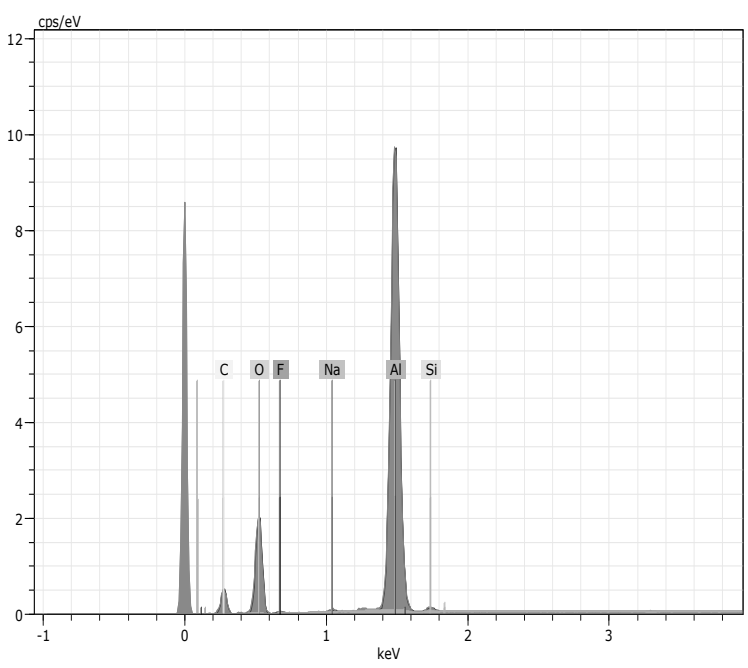

Fig. 5 Surface EDS analysis from visible area in Fig. 4
White particles which were presented on the fracture surface at sample 1-4, one of them is marked at Fig. 4 with the yellow square, had the higher content of $\mathrm{Na}, \mathrm{Cl}$, and $\mathrm{K}$, except basic elements fundamental material. According to this fact could be supposed that the presence of these elements is due to rest of refining salts in material what he says high content of oxygen (45.88 wt. \%) and aluminum (very fine oxides).

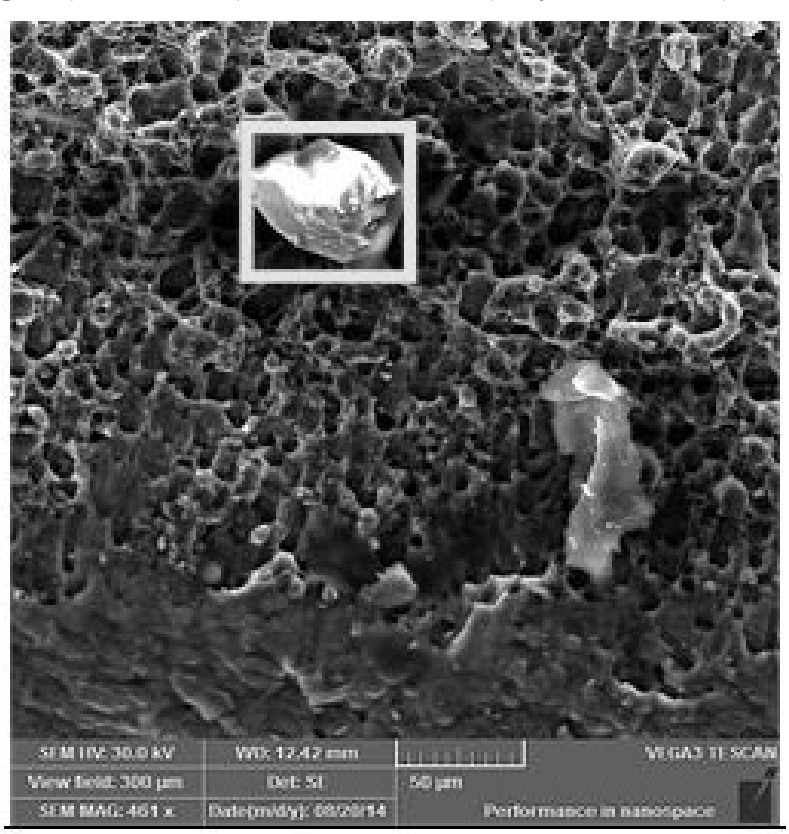

Fig. 4 Detail of fracture surface 
Tab. 3 Results of EDS analysis from the area visible in Fig. 4

\begin{tabular}{|c|c|c|c|c|c|}
\hline 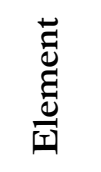 & $\cdot \frac{\mathscr{d}}{\mathscr{D}}$ & 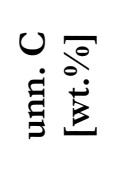 & U & 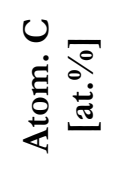 & 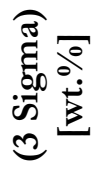 \\
\hline Al & K-series & 33.70 & 31.67 & 19.90 & 5.20 \\
\hline $\mathbf{O}$ & K-series & 45.88 & 43.12 & 45.71 & 21.16 \\
\hline $\mathbf{F}$ & K-series & 1.35 & 1.27 & 1.14 & 1.91 \\
\hline Si & K-series & 0.46 & 0.43 & 0.26 & 0.19 \\
\hline $\mathrm{Na}$ & K-series & 0.32 & 0.30 & 0.22 & 0.20 \\
\hline $\mathrm{C}$ & K-series & 24.70 & 23.21 & 32.78 & 15.86 \\
\hline Total: & & 106.41 & 100.00 & 100.00 & \\
\hline
\end{tabular}

\section{Sample 2-1}

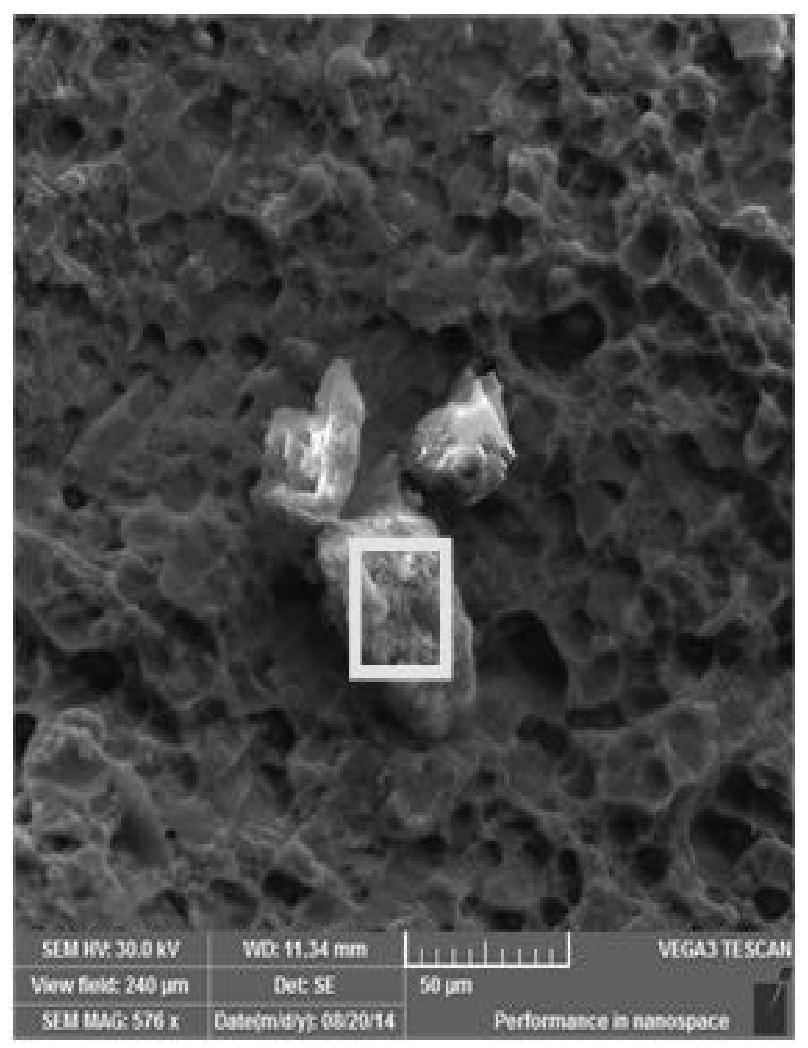

Fig. 6 Detail of fracture surface
In the sample 2-1 it consists of many particles which were visible on the fracture surface, Fig. 6. EDS analysis from the yellow square are presented in Fig. 7, and Table 4. EDS analysis proved the higher content of $\mathrm{Na}, \mathrm{Ca}$, and $\mathrm{F}$. According to this fact could be supposed that the presence of these elements is due to rest of refining salts in material what he says high content of oxygen $(32,19 \mathrm{wt} . \%)$ and aluminum (very fine oxides).

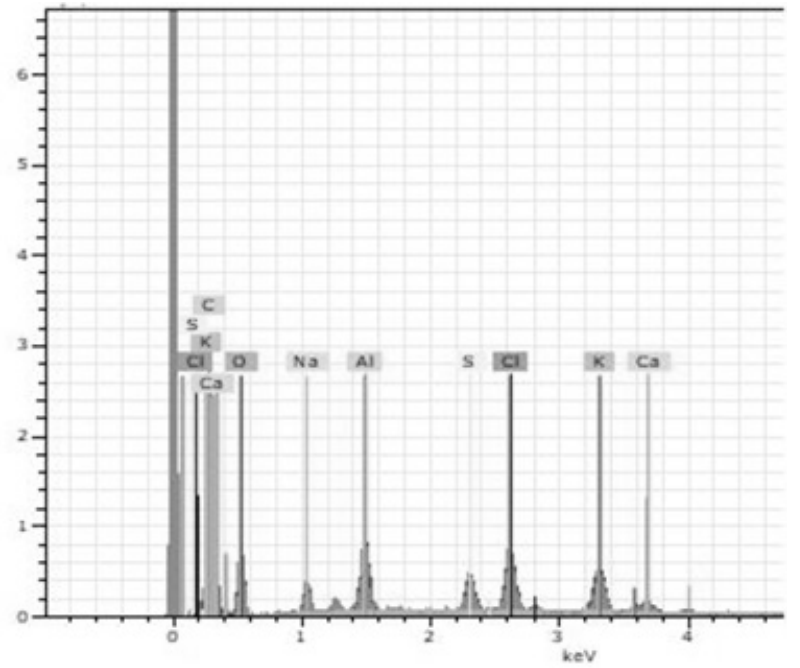

Fig. 7 Surface EDS analysis from visible area in Fig. 6

Tab. 4 Results of EDS analysis from the area visible in Fig. 6

\begin{tabular}{|c|c|c|c|c|c|}
\hline 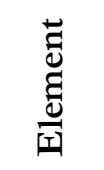 & 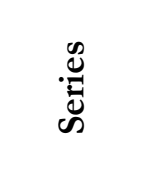 & $\begin{array}{l}0 \\
\dot{g} \\
\end{array}$ & 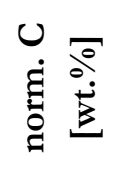 & 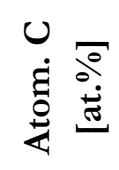 & 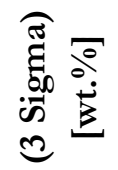 \\
\hline O & K-series & 32.19 & 36.29 & 46.94 & 23.61 \\
\hline $\mathrm{Ca}$ & K-series & 24.49 & 27.61 & 14.26 & 2.39 \\
\hline $\mathrm{S}$ & K-series & 16.01 & 18.05 & 11.65 & 1.96 \\
\hline $\mathrm{Al}$ & K-series & 3.67 & 4.13 & 3.17 & 0.77 \\
\hline $\mathrm{C}$ & K-series & 12.35 & 13.92 & 23.98 & 14.01 \\
\hline Total: & & 88.71 & 100.00 & 100.00 & \\
\hline
\end{tabular}




\section{Sample 4-4}

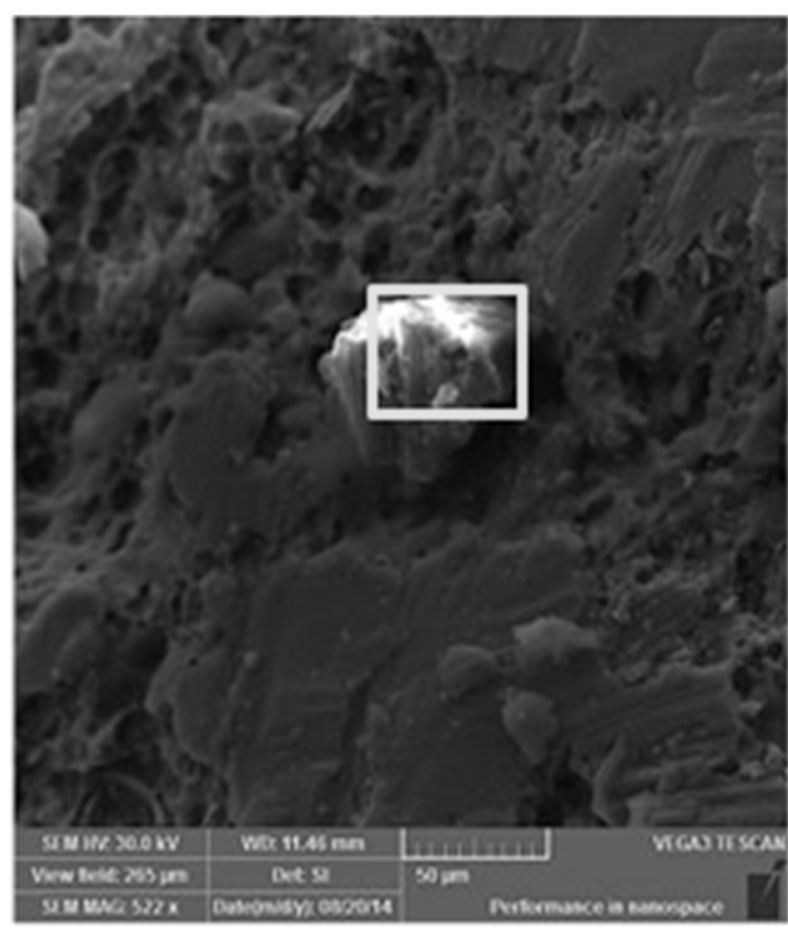

Fig. 8 Detail of fracture surface
In Fig. 8 on the fracture surface foreign particle is presented, taking the area is marked with the yellow square. Results of this analysis is given in Fig. 9 and Table 5. Analyzed particle had the higher content of $\mathrm{Na}, \mathrm{Cl}, \mathrm{K}$ and $\mathrm{S}$ except basic elements. According to this fact could be supposed that the presence of these elements is due to rest of refining salts in material. Such particles were identified in all samples of analyzed sheets 1-5.

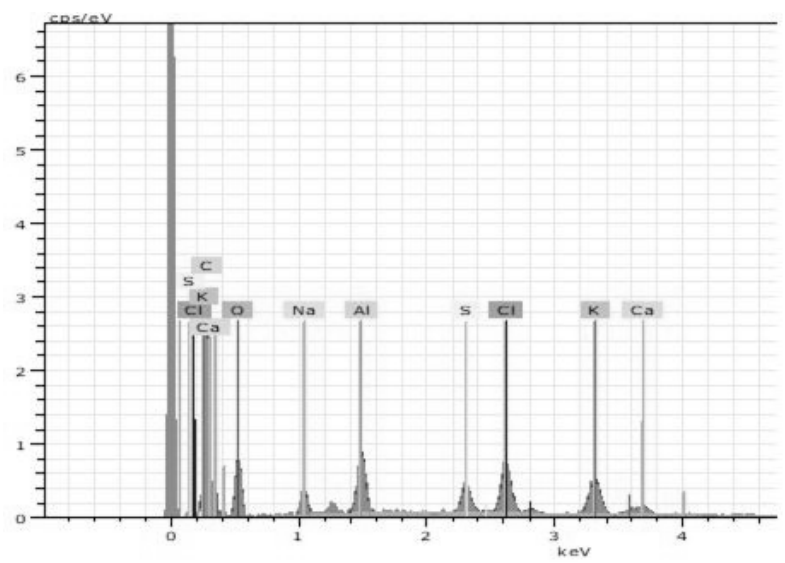

Fig. 9 Surface EDS analysis from area visible in Fig. 8

Tab. 5 Results of EDS analysis from the area visible in Fig. 8

\begin{tabular}{|c|c|c|c|c|c|}
\hline 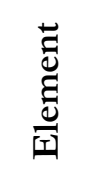 & 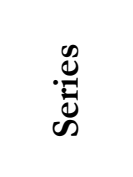 & 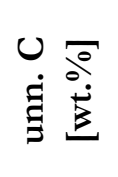 & 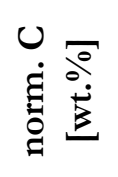 & 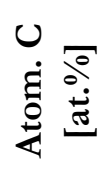 & 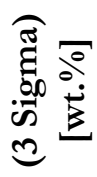 \\
\hline $\mathbf{O}$ & K-series & 34.87 & 30.08 & 26.22 & 24.17 \\
\hline Al & K-series & 3.23 & 2.78 & 1.44 & 0.69 \\
\hline $\mathrm{Cl}$ & K-series & 2.49 & 2.15 & 0.84 & 0.42 \\
\hline $\mathrm{Na}$ & K-series & 2.94 & 2.54 & 1.54 & 0.93 \\
\hline K & K-series & 1.99 & 1.72 & 0.61 & 0.35 \\
\hline$S$ & K-series & 1.24 & 1.07 & 0.46 & 0.29 \\
\hline C & K-series & 68.63 & 59.19 & 68.72 & 37.30 \\
\hline $\mathrm{Ca}$ & K-series & 0.56 & 0.48 & 0.17 & 0.20 \\
\hline Total: & & 115.95 & 100.00 & 100.00 & \\
\hline
\end{tabular}

\section{Analysis of grain size}

For this part of analysis had been used optical microscopy Olympus BX $51 \mathrm{M}$ for observation of microstructure all samples in polarized light. Samples which were prepared from the rolling direction had been brushed and polished. After polishing the samples had been etched by anodic oxidation according to Barker method. Reason for such preparing of samples had been possibility color observation microstructure in polarized light. Documentary of all samples had been made at one hundred magnification. Sheet 5 had the lowest grain size in the contrary to the sheet 3 and 4 which had had the larger grain size.

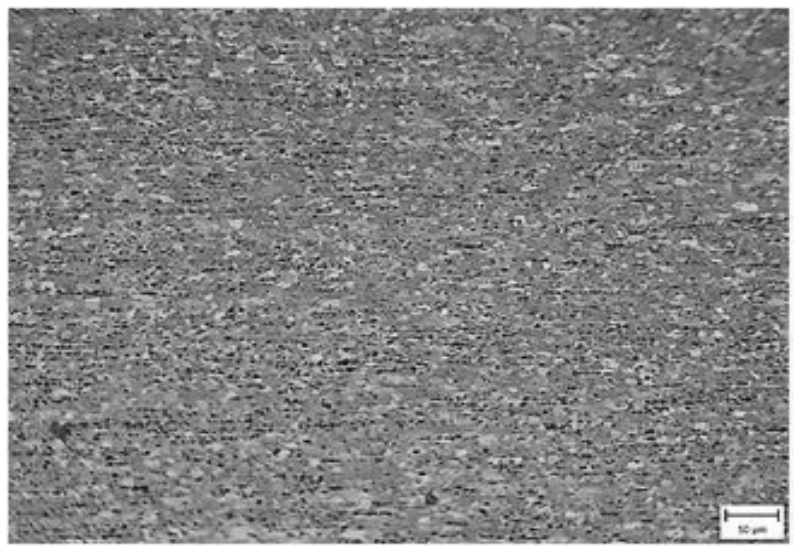

Fig. 10 Sheet 1. Grain size 10-20 $\mu \mathrm{m}$ 


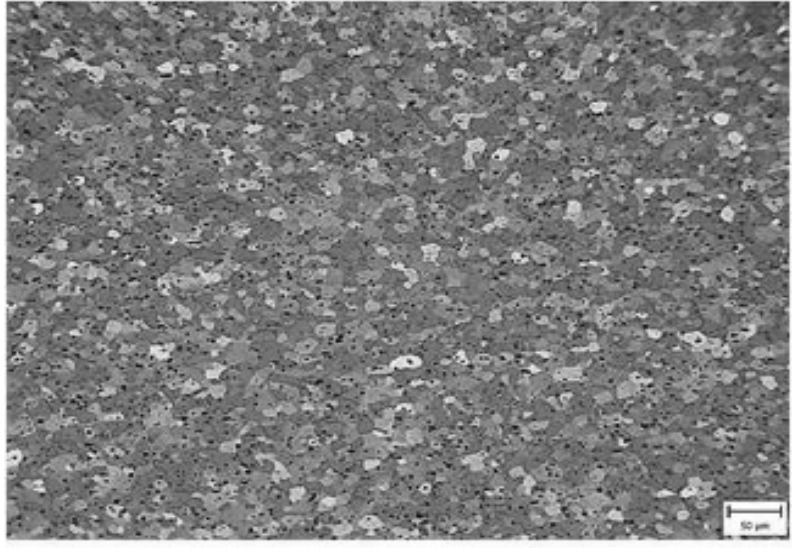

Fig. 11 Sheet 2. Grain size 20-30 $\mu \mathrm{m}$

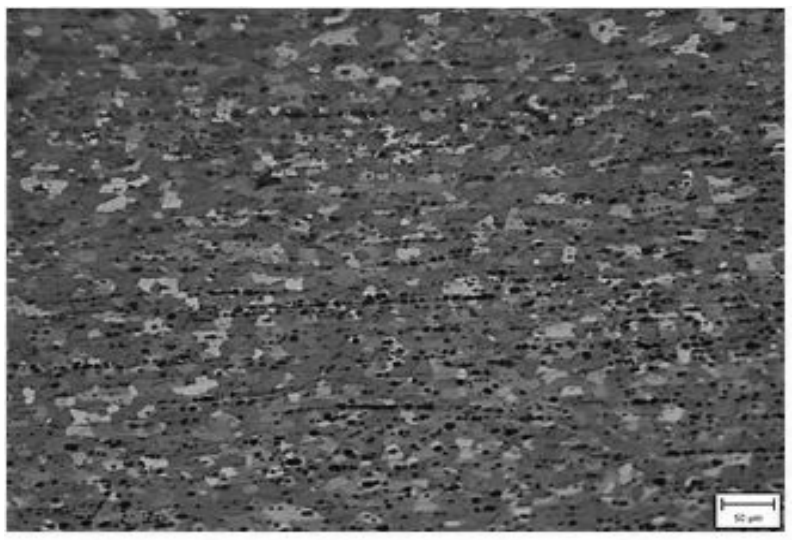

Fig. 12 Sheet 3. Grain size 20-30

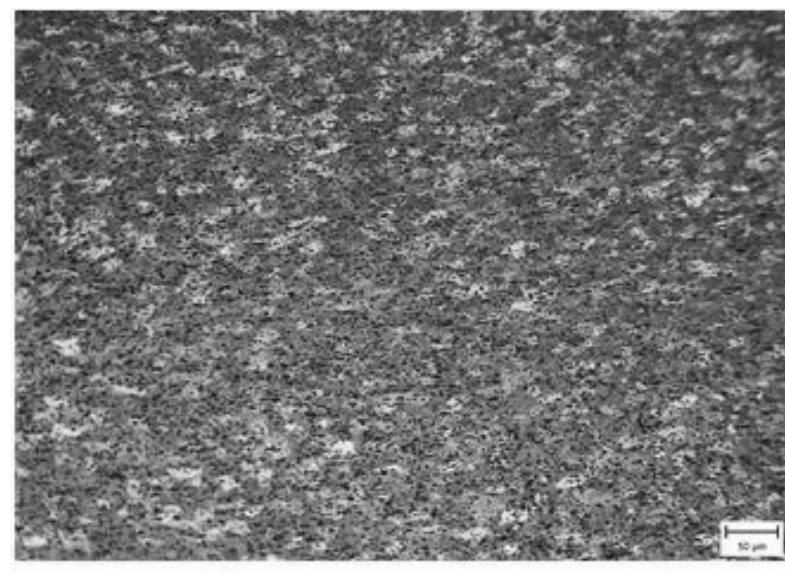

Fig. 13 Sheet 4. Grain size 10-20

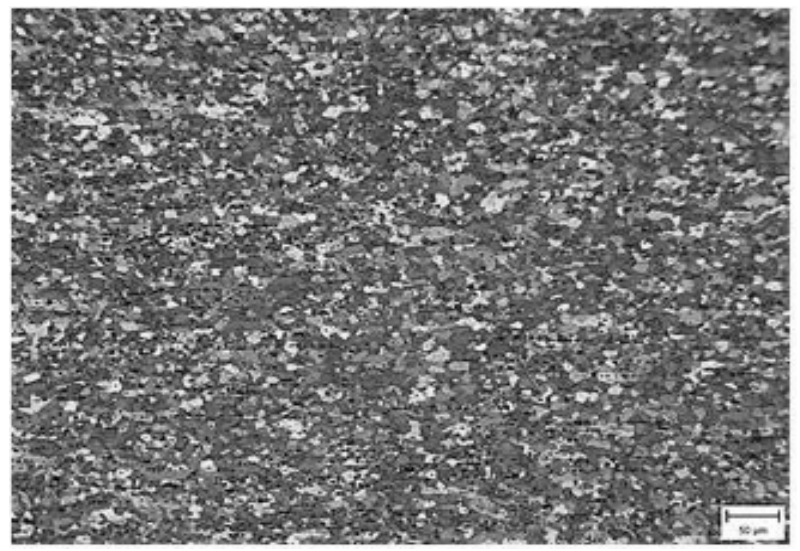

Fig. 14 Sheet 5. Grain size 10-20

\section{Conclusion}

After chemical analysis of the sheets and comparison obtained results it was stated that the sheets 1, 3 and 4 had higher content admixture chemical elements $\mathrm{Si}, \mathrm{Mn}$ and Fe. Content of these elements was 2-3 times higher as had sheet 2. Presence of these elements was reason production of intermetallic particles which had been observed by microstructural analysis. Such a way amount intermetallic particle was higher, and were reason the lower plasticity of materials and deep-drawing properties. Sheet 1 had 0.425 wt. \% Fe, sheet 3 had 0.718 wt. $\%$ Fe, and sheet 4 had 0.710 wt. $\%$ Fe. More over the sheets 3 and 4 had higher content $\mathrm{Cr}$ (in average 0.157 wt. \%) against the other sheets. We recommend summary content of $\mathrm{Fe}+\mathrm{Mn}$ to be maximum 0.30 wt. $\%$, content of Si $0.1 \%$ wt. $\%$, and $\mathrm{Cr}$ 0.01 wt. $\%$ maximum. This is chemical composition of the sheets 2,5 .

Thanks to increased content of Fe, Mn and Si at sheets 1,3 and 4 we found out in microstructure these sheets a lot of intermetallic particles rich with these elements. These particles had even distribution, and had higher size. The sheet 2 had intermedia phase type $\mathrm{Al}-\mathrm{Fe}-\mathrm{Mg}-\mathrm{Mn}-(\mathrm{Ni})$ without presence of $\mathrm{Si}$ to a less extent, and their morphology were finer (phase expelled in the rectangular morphology). In the microstructure of sheet 5, thanks to lower content of $\mathrm{Mn}$ and $\mathrm{Si}$, the presence of intermedia phase on base $\mathrm{Al}-\mathrm{Fe}-\mathrm{Mg}$ (without presence Mn and Si elements) was observed.

Influence of chemical composition on elongation as one of the most important parameters (higher value of elongation guaranteed higher deep-drawing value at produced sheets) having influence on deep-drawing sheets proved obtained values of elongation, where the highest values had been found at samples made of sheet 5 . These samples had elongation in rolling direction $35.1 \%$, and in perpendicular to rolling direction $34.8 \%$. Compared with sheets 1,3 and 4 and also sheet 2 it proved higher elongation as in rolling direction $24.7 \%$ as in perpendicular to rolling direction $24.1 \%$. We recommend for the good deep-drawing to obtain minimum elongation on the level 24-25\% (sheet 2, 5) at sheets made of AlMg3 alloy.

According to the EDS analysis of foreign particles we observed higher content of $\mathrm{Ca}, \mathrm{Na}, \mathrm{K}, \mathrm{Cl}$ respectively $\mathrm{S}$ and $\mathrm{F}$ on fracture surfaces at all samples from the sheets 1-5. Based on this fact the presence of mention elements is likely to be the rest of refining or covered salts. It is proved by high value of oxygen and aluminium, and morphology these particles (fine white oxides). From this point of view it is necessary to state that the presence these foreign particles (intrusions) has negative influence on deep-drawing, and is necessary elimination of their presence in material. We recommend to lower amount of refining and covered salts in the smelting and casting process this material. 


\section{Acknowledgements}

Supported by the OP VVV Project Development of new nano and micro coatings on the surface of selected metallic materials - NANOTECH ITI II., Reg. No CZ.02.1.01/0.0/0.0/18_069/0010045

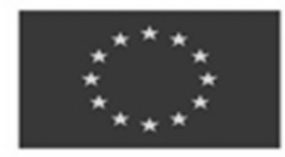

EUROPEAN UNION

European Structural and Investment Funds

Operational Programme Research,

Development and Education

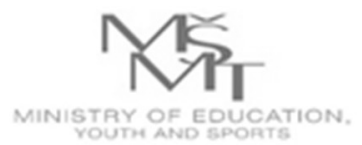

\section{References}

[1] BANABIC D. (2010). Sheet Metal Forming Process. Springer. ISBN 978-3-540-88113-1.

[2] https://www.opi.zcu.cz/mechvlast.html

[3] HLUCHÝ. M., KOLOUCH J. (2007). Strojirenská technologie 1 - Nauka omateriálu. Praha: Scientia. ISBN 978-80-86960-26-5.

[4] HREN, I., MICHNA, Š., MICHNOVÁ, L. (2018). Dependence of mechanical properties on porosity of AlSi7 Mg0.3 alloy during gravity casting. Engineering for Rural Development, Vol. 18, pp. 1001-1006.

[5] HREN, I., MICHNA, Š., CAIS, J., MICHNOVÁ, L., SVOBODOVÁ, J., HODINÁŘ, L. (2018). Beryllium influence on the modification in Al-Si alloy. Metallofizika a Noveishie Technologii, Vol. 12, pp. 1637-1647.

[6] MICHNA, Š. a kol. (2005). Encyklopedie bliníku. 1. Vydání, Prešov, SR: Adin s. r. o., 700 p.

[7] BOLIBRUCHOVÁ., TILLOVÁ, E. (2005). Zlievarenské zliatiny Al-Si. Žilina: EDIS - vydavatel'stvo ŽU.

[8] MONDOLFO L. F. (1979). Aluminium Alloys, Structure and Properties. London: Butterworths, $986 \mathrm{p}$.
[9] MICHNA Š., KUŚMIERCZAK S. (2012). Praktická metalografie. Ústí nad Labem: UJEP in Ústí nad Labem, print OPTYS spol s.r.o., r., $245 \mathrm{p}$.

[10] CAIS J., MICHNA Š. (2015). Research of Influence of Heat Treatment on Microstructure and Mechanical Properties of AlSi9CuNiMn Alloy. Manufacturing Technology, Vol. 15, N.5, pp. 43-46.

[11] MICHNA Š., CAIS J., MICHNOVÁ L. (2015). Research of the Cause Cracking Hot-Rolled Block Made of AlMg5 Alloys. Manufacturing Technology, Vol. 15, No. 4, pp. 614-620.

[12] MARCHWICA, P. (2012). Microstructual and Thermal Analysis of Aluminum-Silicon and Magnesium-Aluminum Alloys Subjected to High Cooling Rates. Electronic Theses and Dissertations. 557

[13] UHRÍČIK, M., PALČEK, P., CHALUPOVÁ, M., ORŠULOVÁ, T. (2017). The Structure of the Aluminium Alloy and Its Influence on the Fatigue Properties. Manufacturing Technology. Vol. 17, No. 6, pp. 863-869.

[14] NACHTNEBL, P., KOLAŘíK, L., FOREJTOVÁ, L., REISGEN, U., BEHR, W. (2018) Ultrasonic Testing of Diffusion Bonded Joints of AlMg3. Manufacturing Technology. Vol. 18, No.2, pp. 289-294. 